\title{
EXCESS COPPER INDUCES STRUCTURAL CHANGES IN CULTURED PHOTOSYNTHETIC SOYBEAN CELLS
}

\author{
María Bernal $^{1}$, Pilar Sánchez-Testillano², María del Carmen Risueño ${ }^{2}$, \\ Inmaculada Yruela ${ }^{1, *}$
}

${ }^{1}$ Estación Experimental de Aula Dei, Consejo Superior de Investigaciones

Científicas (CSIC), Avda. Montañana 1005, 50095 Zaragoza, España.

${ }^{2}$ Centro de Investigaciones Biológicas, Consejo Superior de Investigaciones

Científicas (CSIC), C/ Ramiro de Maeztu 9, 28040 Madrid, España.

Corresponding author: Inmaculada Yruela;

Estación Experimental de Aula Dei, Consejo Superior de Investigaciones Científicas, Apdo. 202, E-50080 Zaragoza, Spain.

yruela@eead.csic.es, Fax: +34 976 716145, Phone: +34 976716058 


\section{ABSTRACT}

Soybean cell suspensions have the capacity to develop tolerance to excess copper, constituting a convenient system for studies on the mechanisms of copper tolerance. The functional cell organization changes observed in these cell cultures after both a short-term (stressed cells) and a long-term (acclimated cells) $10 \mu \mathrm{M} \mathrm{CuSO}_{4}$ exposure are reported by using a structural, cytochemical and microanalytical approach. Cells grown in the presence of $10 \mu \mathrm{M} \mathrm{CuSO} 4$ shared some main structural features with non-treated cells such as: i) a large cytoplasmic vacuole; ii) chloroplasts along the thin layer of cytoplasm; iii) nucleus in a peripheral location exhibiting circular-shaped nucleolus and a decondensed chromatin pattern; iv) presence of Cajal bodies in the cell nuclei. In addition, cells exposed to $10 \mu \mathrm{M} \mathrm{CuSO}$ exhibited important differences compared with non-treated cells: i) chloroplasts displayed rounded shape and smaller size with a denser structured internal membranes specially in copper acclimated cells; ii) no starch granules were found within chloroplasts; iii) cytoplasmic vacuole was larger specially after a long-term copper exposure; iv) the levels of citrate and malate increased. Extracelullar dark deposits attached at the outer surface of the cell wall with high copper content were only observed during a short-term copper exposure as a differential feature. Structural cell modifications, mainly affecting chloroplasts, accompanied the short-term copper induced response and were maintained as a stable character during the adaptive period to excess copper. Vacuolar changes rather accompanied the long-term copper response. The results indicate that the first response of soybean cells to excess copper avoids its entrance to the cell by its immobilization in the cell wall, and after an adaptive period copper acclimation may be mainly due to vacuolar sequestration. 
Keywords: acclimation, copper, microscopical structural analysis, organic acids, soybean cell culture, tolerance

Abbreviations: Chl, chlorophyll; DAPI, 4'-6-diamidino-2-phenylindole; EDX, energy dispersive X-ray; LTSME; low temperature scanning electron microscopy. 


\section{INTRODUCTION}

Copper $(\mathrm{Cu})$ is an essential micronutrient for plants. Copper acts as a structural element in certain metalloproteins, many of which are involved in electron transport in mitochondria and chloroplasts, and oxidative stress response (Raven et al. 1999; Gratão et al. 2005). It also participates in cell wall metabolism, hormone signalling, protein trafficking machinery, transcription signalling and iron mobilization (for reviews see Yruela 2005; Pilon et al. 2006). Nevertheless, it can also be a toxic element at a tissue concentration slightly higher (20-30 $\mu \mathrm{g} \mathrm{g}^{-1}$ dry weight) than the normal one (6-12 $\mu \mathrm{g} \mathrm{g}^{-1}$ dry weight) (Baker and Senef 1995; Marschner 1995). Although normally copper binds to proteins, it may be released and become free to catalyze the formation of highly reactive hydroxyl radicals via Fenton-type reactions. Thus, copper has capacity to initiate oxidative damage and interfere with important cellular processes such as photosynthesis, pigment synthesis, plasma membrane permeability and other metabolic mechanisms causing a strong inhibition of plant development (Küpper et al. 2003; Bertrand and Poirier 2005; Yruela 2005). Since copper is both an essential cofactor and a toxic element its uptake and cellular concentrations must be strictly regulated. Thus, plants use different strategies to appropriately regulate copper homeostasis as a function of copper environmental level (Pilon et al. 2006; Krämer and Clemens 2006).

At present, there is an increasing concern about copper toxicity in agriculture and health since copper is considered a major heavy metal contaminant that results from fertilizers accumulation, the application of pig and poultry slurries rich in copper, fungicides, industrial and urban activities, mining or metal processing (Kabata-Pendias and Pendias 2001; Pilon-Smits and Pilon 2002). Copper concentration in non-contaminated soils and natural waters is ca. 
20-30 mg kg-1 and $2 \mu \mathrm{g} \mathrm{kg}^{-1}$, respectively but in contaminated soils and waters can reach levels one hundred times higher (Fernandes and Henriques 1991). Some plant species or ecotypes are sensitive to metals, whereas others are tolerant showing little growth inhibition or damage even if they grow in severely polluted soils and accumulate high concentrations of these elements in their tissues. It was demonstrated that the plant Silene vulgaris exhibits tolerance to different metals (Zn, Cd or Cu) (Schat et al. 1997; Van Hoof et al. 2001). Different response to excess copper were observed in four Australian tree species, Acacia holosericea, Eucalyptus crebra, Eucalyptus camaldulensis and Melaleuca leucadendra (Reichman et al. 2006). Nowadays, mechanisms of heavy metal tolerance in plants are of interest and numerous works have been conducted on this subject. In general, control of metal uptake, excretion of accumulated metals and intracellular immobilization of those are the main mechanisms that operate alone or in concert to protect plants from toxic effects (Ernst et al. 1992; Clemens 2001; Hall and Williams 2003; Kramer and Clemens 2006). However, in some cases the mechanisms underlying the tolerance to metals are not fully understood and in particular those mechanisms related to copper tolerance. In soybean seedlings treated with excess copper it has been reported that the enhancement in peroxidase and laccase activities was accompanied by a rapid increase of lignin contents in the copper treated tissues (Lin et al. 2005). The increase in phenolic compounds, related enzymes and lignin was observed in root suspension cultures of Panax gingseng in response to copper stress (Ali et al. 2006). Intraspecific and interspecific differences in sensitivity to copper do occur between different plant species. On the other hand, with regard to mechanisms allowing a copper tolerance, a question of 
interest is whether this tolerance is constitutive in each species or depends on previous long-term exposure to metal.

Plant cell cultures are widely used as suitable model system to analyse metabolic signalling pathways, developmental process and cell stress response and adaptation, among many other studies on plant physiology (Roitsch and Sinha, 2002; Allan et al. 2006; Zuppini et al. 2006). Plant cell cultures can be a useful tool for studying the characteristics and mechanisms of heavy metal tolerance in plants at cellular level. In this respect, only a few studies concerning heavy metal tolerance in plant cell suspensions exist. Selection and characterization of various cell cultures from Nicotiana tolerant to aluminium, cadmium, copper and zinc have been reported (Kishinami and Widholm 1986, 1987; Gori et al. 1998). Cadmium stress has been studied in sugar cane callus cultures (Fornazier et al. 2002). However, a very little information exist from cell suspensions of other species. Since the cell culture used in this work comes from mesophyll cells, the results presented here may provide information to advance in our knowledge of physiological aspects of leaf cells in plants. In a previous paper we reported that soybean cell suspensions have capacity to develop tolerance up to $50 \mu \mathrm{M} \mathrm{CuSO}_{4}$ after a long-time copper exposure (Bernal et al. 2006). In this work we investigated more in detail the structural cellular changes induced by excess copper on soybean cell suspensions. The comparison between a short-term and a long-term copper exposure is presented. 


\section{MATERIALS AND METHODS}

Cell culture conditions.- Photosynthetic cell cultures from soybean (Glycine max var. Corsoy) SB-P line were grown as described by Rogers et al. (1987) with some modifications. Cell suspensions were grown in liquid cultures photomixotrophically ( $\mathrm{KN}^{1}$ medium) under continuous low light $\left(30 \pm 5 \mu \mathrm{E} \mathrm{m} \mathrm{m}^{-2}\right.$ $\left.\mathrm{s}^{-1}\right)$. The $\mathrm{KN}^{1}$ medium contained thiamine $(0.1 \mathrm{mg} / \mathrm{L})$, kinetin $(0.2 \mathrm{mg} / \mathrm{L})$, naphthalene acetic acid (1 mg/L) and sucrose (1\% w/v) as organic components. It has been reported that this kind of cultures grow optimally with $65-75 \mu \mathrm{E} \mathrm{m}{ }^{-2}$ $\mathrm{S}^{-1}$ (Alfonso et al. 1996) and that high light cause photoinhibitory effects in these cell suspensions (personal communication; Alfonso et al. 1996). On the other hand, it is known that copper is a potential toxic element and its toxicity enhances with light. Thus, we decided to assay a low light regime (30 $\pm 5 \mu \mathrm{E} \mathrm{m}{ }^{-}$ ${ }^{2} \mathrm{~s}^{-1}$ ) following the light conditions used in previous works studying the copper stress effect on cell cultures (Gori et al. 1998, Bernal et al. 2006). To assay the copper effect on cell growth the media were supplemented with $10 \mu \mathrm{M} \mathrm{CuSO}_{4}$.

$5 \mathrm{H}_{2} \mathrm{O}$. Control medium corresponded to $0.1 \mu \mathrm{M} \mathrm{CuSO}_{4} \cdot 5 \mathrm{H}_{2} \mathrm{O}$. Cell suspensions were sub-cultured each 23 days of growth (one transfer) by using fresh media containing the appropriated copper concentrations. For experiments cells were collected after the first 21 days of growth in the presence of $0.1 \mu \mathrm{M} \mathrm{CuSO} 4$ (non-treated cells) and $10 \mu \mathrm{M} \mathrm{CuSO}$ (Cu-stressed cells), and after 22 transfers in the presence of $10 \mu \mathrm{M} \mathrm{CuSO}{ }_{4}$ (Cu-acclimated cells). For microscopical structural analysis, soybean cells were grown in $1.5 \%(w / v)$ agar plates with $\mathrm{KN}^{1}$ medium at $24^{\circ} \mathrm{C}$ and atmosphere with $5 \% \mathrm{CO}_{2}$. Cells cultured in these conditions were easier to handle during the fixation and sectioning procedures than liquid suspensions. 
Sample processing for microscopical structural analysis.- Soybean cells were fixed overnight at $4^{\circ} \mathrm{C}$ in $4 \%(\mathrm{w} / \mathrm{v})$ formaldehyde in phosphate buffered saline solution (PBS), pH 7.3. Then, they were washed in PBS and dehydrated through an acetone series $(30 \%, 50 \%, 70 \%$ and $100 \%(\mathrm{v} / \mathrm{v}))$ at $4^{\circ} \mathrm{C}$. The samples were infiltrated and embedded in Historesin 8100 at $4^{\circ} \mathrm{C}$. Semithin sections ( $1 \mu \mathrm{m}$ thickness) were obtained and used for light microscopy observations. Toluidine-blue stained semithin sections were observed under bright field and phase contrast field for structural analysis in a Leitz microscope fitted with a digital camera Olympus DP10.

Morphometric analysis of cell, chloroplast and vacuole size.- Random sampling was carried out over toluidine-stained micrographs of the three cultures. The number of micrographs to be taken was determined using the progressive mean test, with a maximum confidence limit of $p \leq 0.05$. The cell, chloroplast and vacuolar area was measured in $\mu^{2}$ using a square lattice composed by $40 \times 57$ squares of $5 \times 5 \mathrm{~mm}$ (cell and vacuole) or $65 \times 96$ squares of $3 \times 3 \mathrm{~mm}$ (chloroplast) each. For each culture, the mean area per cell was estimated and the results were compared among the cultures. Duncan's multiple range test $(p \leq 0.05)$ was used to compare the data among the cultures.

Cytochemical stainings for starch and DNA.- Starch was detected by $\mathrm{I}_{2} \mathrm{KI}$ staining (O'Brien and McCully 1981) on Historesin semithin sections and observed under bright field (Barany et al. 2005). DAPI staining for DNA was applied to semithin sections (Testillano et al. 1995) and observed under UV light in a Zeiss Axiophot epifluorescence microscope fitted with a CCD camera. 
Copper determination.- Cells were harvested and washed twice with $3 \mathrm{mM}$ EDTA and once with distilled $\mathrm{H}_{2} \mathrm{O}$ to remove free cations. After washing, cells were filtered through a layer of Miracloth (Calbiochem, EMD Biosciences Inc, San Diego, CA, USA) and dried in a ventilated oven at $60{ }^{\circ} \mathrm{C}$ for $48 \mathrm{~h}$. Dried samples were treated using a standard procedure (Abadía et al. 1985). Analyses were performed in an atomic absorption spectrometer (UNICAN 969).

Organic acids analysis.- Cells were harvested on Miracloth layer (Calbiochem, EMD Biosciences Inc, San Diego, CA, USA), washed three times with cold distilled water and then homogenized in $70 \%(\mathrm{v} / \mathrm{v})$ ethanol in a Teflon homogenizer. The homogenate was centrifuged at $10,000 \times \mathrm{g}$ for $10 \mathrm{~min}$ at $4^{\circ} \mathrm{C}$ and the pellet was washed with $70 \%(\mathrm{v} / \mathrm{v})$ ethanol three times. The supernatants were combined and dried under vacuum at $35^{\circ} \mathrm{C}$ in SPD Speed Vac model SPD111V (Thermo Savant, Holbrook, NY, USA). The residue was resuspended in $0.1 \%(\mathrm{v} / \mathrm{v})$ formic acid and filtered with $0.2 \mu \mathrm{m}$ nylon filter (Tecknokroma, Barcelona, Spain), taken to a final volume of $0.5 \mathrm{ml}$ and stored at $-80^{\circ} \mathrm{C}$ until analysis. Organic acids were analysed by HPLC-ESI/MS with a BioTOF® II (Bruker Daltonics, Billerica, MA, US) coaxial multipass time of flight mass spectrometer (MS (TOF)) equipped with an Apollo electrospray ionization source (ESI), and coupled to a Waters Alliance 2795 HPLC system (Waters Corp., Mildford, MA, US) with a Supelcogel H 250 x 4,6 mm column. The mobile phase was $0.1 \%(v / v)$ formic acid. Duncan's multiple range test $(p \leq 0.05)$ was used to compare the data among the cultures. 
Energy-dispersive X-ray microanalysis.- Cells were cry fixed using a highpressure freezer (Leica EMPact; Leica Microsystems, Gladesville, Australia) and were then stored in liquid nitrogen until freeze-substitution. Frozen cells were freeze-substituted with diethyl ether containing $10 \%$ acrolein with freshly activated $5 \AA$ molecular sieve (Baker Analyzed) for 4 days at $-90^{\circ} \mathrm{C}, 2$ days at $70^{\circ} \mathrm{C}$ and 1 day at $-30^{\circ} \mathrm{C}$. Subsequently, samples were gradually brought to $4^{\circ} \mathrm{C}$ by raising the temperature for $1.5 \mathrm{~h}$ (Bidwell et al. 2004). The freeze-substituted cells were infiltrated with Araldite resin over 4 days. Araldite contains negligible levels of elements detectable by energy-dispersive spectrometry (Pålsgård et al. 1994). Cell sections were cut dry at $0.5 \mu \mathrm{m}$ using an ultramicrotome (Leica Ultracut UCT) and mounted directly onto titanium grids (75 mesh) that were coated with formvar. Sections were stored in a desiccator under vacuum until analysis to prevent absorption atmospheric water and hence possible redistribution of ions.

Unstained sections were analysed at room temperature in a carbon holder by energy-dispersive X-ray microanalysis using a transmission electron microscope (model H-800-MT, Hitachi) and X-ray EDX Quantum detector (model 3600, Kevex). The detector was interfaced to a signal processing unit (Röntec, Ltd, Normanton, UK). The electron microscope was operated at 100 $\mathrm{kV}$ in STEM mode with a spot size $10-15 \mathrm{~nm}$ and a beam current $15 \mu \mathrm{A}$. The spectral data from individual cells and compartments in each section were collected using selected area analysis with an acquisition time of $300 \mathrm{~s}$. Analyses were carried out by Quantax 1.5 program (Röntec Ltd, Normanton, UK). Spectra were normalized at titanium peak used as an internal standard, which came from the grid material. 
Low Temperature Scanning Electron Microscopy (LTSEM).- Samples were examined by using the Low Temperature Scanning Electron Microscopy LTSEM technique (De los Ríos et al. 2004). Cells were mechanically fixed onto the specimen holder of a cryotransfer system (Oxford CT1500), plunged into subcooled liquid nitrogen, and then transferred to a preparation unit via an air lock transfer device. The frozen specimens were cryofractured and transferred directly via a second air lock to the microscope cold stage, where they were etched for $2 \mathrm{~min}$ at $-90^{\circ} \mathrm{C}$. After ice sublimation, the etched surfaces were sputter coated with gold in the preparation unit. Samples were subsequently transferred onto the cold stage of the scanning electron microscope chamber. Fractured surfaces were observed with a DSM 960 Zeiss scanning electron microscope at $-135^{\circ} \mathrm{C}$. 


\section{RESULTS}

The main features of the cell structure in the soybean photosynthetic cell cultures grown in control medium (non-treated cells) and in the presence of 10 $\mu \mathrm{M} \mathrm{CuSO}{ }_{4}$ after either the first 21 days of copper treatment (Cu-stressed cells), or 22 transfers exposed to excess copper (Cu-acclimated cells) were analyzed (for details see Materials and Methods). Cells accumulated copper during the first 21 days of growth in the presence of $10 \mu \mathrm{M} \mathrm{CuSO}{ }_{4}$ and the copper concentration in acclimated cells even slightly increased during the $10 \mu \mathrm{M}$ $\mathrm{CuSO}_{4}$ treatment (Fig. 1). Semithin sections were observed at light microscopy after different staining and cytochemical procedures (Figs. 2-4): i) toluidine blue for general structural analysis; ii) iodide-based staining to reveal starch and iii) DAPI for DNA. The observations revealed common and differential features in the structural organization of cells from different cultures assayed. Scanning electron microscopy observations are also shown in Fig. 5.

Cells of the three types of in vitro cultures studied, with different copper concentrations and times (non-treated, Cu-stressed and Cu-acclimated), shared some main structural features and exhibited several differences, which characterized their structural organization. Non-treated cells (Fig. 2, 5a), Custressed cells (Fig. 3, 5b) and Cu-acclimated cells (Fig. 4, 5c) showed rounded shape, most of them with a large cytoplasmic vacuole occupying a high proportion (ca. 50-60\%) of the cellular volume; the rest of the cytoplasm appeared as a thin peripheral layer containing numerous chloroplasts. Cells grown under the three culture conditions assayed were found either isolated or forming spherical structures with two cells; the two-cell structures were divided by a straight cell wall located in a lateral position, probably originated by the asymmetric division of individual isolated cells (Figs. 2a, b, f-h; 3a; 4a, b). The 
nucleus was observed in a peripheral location exhibiting a patent and circularshaped nucleolus (Figs. 2b, f-h; 3b, c; 4b, c), and a pattern of chromatin mostly decondensed, with several small patches of heterochromatin in linear arrays along to the nuclear envelope, as clearly seen by DAPI staining (Fig. 2c). Nuclear bodies were frequently observed in the cell nuclei of the photosynthetic cultures as small rounded structures of medium contrast in toluidine-blue stained preparations (arrows in Figs. 2f, h, and open arrow in Fig. 3b). Their size, localization and presence were similar to that of Cajal bodies, ribonucleoprotein structures found in most eukaryotic cells and also described in plants (Risueño and Medina, 1986; Beven et al. 1995). They are typical structures of metabolically-active and proliferating plant cells (Beven et al. 1995, Testillano et al. 2005, Seguí-Simarro et al. 2006). Morphometric analysis revealed a similar cellular size in non-treated, Cu-stressed and Cu-acclimated cells, with no statistically significant differences (Table 1).

The main differences observed among the cellular types of the three cultures affected chloroplasts, starch granules, vacuoles and extracellular deposits. Chloroplasts of non-treated cells were ellipsoids (Fig. 2a, b, f-h) and most of them contained large starch deposits, as revealed by the iodide-based cytochemistry (Fig. 2d, e); the starch granules were clearly observed at LTSEM occupying large volumes in the chloroplast (Fig. 5a). In contrast, chloroplasts of Cu-stressed and Cu-acclimated cells lost the ellipsoidal shape and displayed rounded shape (Figs. 3b, c; 4b, c; 5b, c). The chloroplast size in these cells was on average 2-fold and 3-fold smaller, respectively, compared with those of nontreated cells (Table 1). Moreover, chloroplasts of Cu-acclimated cells appeared more numerous with denser structured internal membrane compared with nontreated cells (Fig. 4b,c). These observations are in agreement with those 
previously reported by Bernal et al. (2006). No starch granules could be found after iodide cytochemistry in copper treated cells (Figs. 3d, e; 4d, e). The cells of $\mathrm{Cu}$-acclimated cultures showed larger cytoplasmic vacuoles than the nontreated cells and Cu-stressed cells, exhibiting a vacuole size 34\% larger (Figs. 4a-c; 5c; Table 1). In Cu-stressed cells, numerous dark and small rounded deposits were observed attached at the outer surface of the cell wall (Fig. 3a, b, $c, f-h)$. The cells of the other cultures did not show similar extracellular features (Figs. 2, 4). EDX microanalyses revealed a high copper content in these attached dark deposits (Fig. 6b). Since low molecular weight metal complexes could be organic acid-metal chelates (Kishinami and Widholm 1987), the levels of citrate and malate were determined in the three types of in vitro cultures studied (Table 2). In Cu-acclimated cells, both citrate and malate content increased to levels 2-3 fold and 3-4 fold higher, respectively, compared with non-treated cells. Interestingly, in Cu-stressed cells citrate increased to levels 34 fold those of non-treated cells and remained or slightly decreased in $\mathrm{Cu}$ acclimated cells. 


\section{DISCUSSION}

In the present work we compare the effect of $10 \mu \mathrm{M} \mathrm{CuSO}{ }_{4}$ on the functional cellular structure of soybean cell cultures after different copper exposure times. This study provided information about which $\mathrm{Cu}$-induced effects on soybean cell structure accompany a short-term and a long-term response associated to adaptive processes. Cells accumulated high copper concentration when they were grown in medium supplemented with $10 \mu \mathrm{M}$ $\mathrm{CuSO}_{4}$ with no toxicity symptoms, in agreement with previous results (Bernal et al. 2006). Tolerance to increased concentrations of copper has been induced in the laboratory in several strains of the algae Scenedesmus and Chlorella (Küpper et al. 2003). The green alga Scenedesmus quadricauda was capable of developing a reversible (i.e. not genetically fixed) high resistance to copper. The results reported here show that the general cell organization pattern of the non-treated soybean cultures is maintained by the cells after the copper treatments. Moreover, cell features typical of proliferating cells were found not only in the non-treated cultures but also in both short- and long-term treated cultures such as nuclear Cajal-like bodies (Beven et al. 1995, Testillano et al. 2005, Seguí-Simarro et al. 2006) or straight thin cell walls dividing spherical two-cell structures (Satpute et al. 2005). The results also showed that the copper exposure induced changes in specific subcellular structures. The main target of copper effect was the chloroplast compartment. Indeed, smaller chloroplasts with a rounded shape were observed in soybean cells grown in the presence of $10 \mu \mathrm{M} \mathrm{CuSO}_{4}$ compared with non-treated ones. This modification was observed either in Cu-stressed or Cu-acclimated cells indicating that this event is a fast Cu-induced response in soybean cell cultures. This finding contrasts with certain observations reported in the literature. For instance, no 
significant alterations in chloroplast size and shape were found in $100 \mu \mathrm{M} \mathrm{Cu}$ tolerant cultures of Nicotiana tabacum (Gori et al. 1998) and mesophyll cells from Triticum durum seeds exposed to 10-50 $\mu \mathrm{M} \mathrm{Cu}$ (Ciscato et al. 1997; Quartacci et al. 2000). Chloroplasts of seven-week-old Arabidopsis thaliana plants exposed to $50 \mu \mathrm{M} \mathrm{Cu}$ during 2-14 days showed similar size that the control ones but rather circular than ellipsoidal shape (Wójcik and Tukiendorf 2003). Different chloroplast response has been found by exposure to other metals, i.e., cadmium (Cd) stress increased the chloroplast size in Myriophyllum spicatum (Stoyanova and Tchakalova 1997) and Raphanus sativus (radish) (Vitória et al. 2004). Our results also showed that chloroplasts in Cu-acclimated cells were more numerous in agreement with Bernal et al. (2006). This higher chloroplast number could maintain a constant plastid to mesophyll cell volume, which could compensate for the reduced chloroplast size. Recently, it has been reported that Arabidopsis thaliana mutants altered in the accumulation and replication of chloroplasts (arc mutants) present reduced chloroplast number and increased plastid size due to a compensatory mechanism (Austin II and Webber 2005).

After copper exposure, starch accumulation in chloroplasts was especially affected either in Cu-stressed or in Cu-acclimated cells. No accumulation of starch was observed in those cells. This finding contrasts with the significant increase in starch observed in seven-week-old Arabidopsis thaliana and cucumber plants exposed to excess copper $\left(100 \mu \mathrm{M}\right.$ and $20 \mu \mathrm{g} \mathrm{g}^{-1}$, respectively) (Wójcik and Tukiendorf 2003; Alaoui-Sossé et al. 2004). Similarly, cadmium or nickel stress was accompanied by an increase in carbohydrate contents in rice seedlings (Moya et al. 1993). Such discrepancies could be due to differences in starch metabolism between plants and cell cultures. The 
relationship between starch accumulation in leaves and chloroplasts from stressed plants and inhibition of photosynthesis is well documented (Foyer 1988; Moya et al. 1993). Starch accumulation may result from a fall in the rate of utilisation of assimilates in the sink organs. Decrease in chlorophyll and sugars, and increase in starch was observed in the medicinal plant Phyllanthus amarus exposed to cadmium stress (Rai et al. 2005). On the contrary, the absence of starch accumulation may be attributed to a faster metabolism of assimilates. In this respect, previous results (Bernal et al. 2006) demonstrated that Cu-acclimated soybean cell suspensions have a higher growth rate as consequence of additional cell division. Starch consuming could be also required for an enhanced antioxidant activity. It has been reported that the induction of glucose-6-phosphate dehydrogenase (G6PDH) could contribute to antioxidant activity by providing more $\mathrm{NADPH}$, which is required for the detoxification of ROS and peroxides (Kuo and Tang 1998; Ali et al. 2006). In this respect we observed no significantly differences in the ascorbate peroxidase (APX) and total superoxide dismutase (SOD) enzyme activities between copper-treated and non-treated cells although Cu/Zn SOD activity was stimulated in cells exposed to excess copper (unpublished data). On the other hand, the photosynthetic oxygen-evolution activity, which generates ROS and peroxides, was stimulated in Cu-acclimated cells in comparison with nontreated cells (Bernal et al. 2006) but this was not the case in Cu-stressed cells. Thus, a clear direct correlation between Cu-induced effect on starch reduction, antioxidant activity and photosynthesis cannot be established in these cell cultures. Interestingly, a correlation between the size of chloroplasts and the content of starch granules could be established. It is worth mentioning that starch accumulation strongly decreased in both Cu-stressed and Cu-acclimated 
cells and this event accompanied the reduction of chloroplast size in those cells. These phenomena were independent of the copper exposure time and they were rather a short-term response than a long-term response as consequence of the excess copper adaptive period. Recently, it has been probed that manipulation of FtsZ expression levels, a key structural component of the chloroplast division machinery, can result in a modified size distribution of starch granules (De Parter et al. 2006). Further investigations are necessary to understand starch metabolism in chloroplasts of soybean cells and its relation with chloroplast division and structure.

The strategies for avoiding heavy metal toxicity are diverse. A first barrier against copper stress can be the immobilization of copper by means of cell wall and extracellular compounds such as organic acids (citrate, malate, oxalate), carbohydrates, proteins or peptides enriched in cysteine or hystidil groups. However, the importance of these mechanisms may vary in accordance with the concentration of metal supplied, the plant species involved and the exposure time. Dark deposits attached at the outer surface of the cell wall containing high level of copper were observed in Cu-stressed cells. Similar deposits have been observed in plants grown under metal stress conditions (Vitória et al. 2006). Interestingly, those dark deposits were not observed in Cu-acclimated cells indicating that their presence is really a short-term response, which disappears with a longer time exposure. Extracellular chelation by organic acids such as citrate and malate is a mechanism of metal tolerance (Rauser 1999). The secretion of organic acids is reasonably well established as a mechanism for aluminium tolerance (Kochian et al. 2004, Mariano et al. 2005), but there is very little number of studies in support of organic acid mechanism for copper tolerance. In this work we show that the accumulation of higher levels of citrate 
and malate takes place in Cu-acclimated cells. Similar levels of citrate and malate in copper tolerant Nicotiana plumbaginifolia cells have been reported (Kishinami and Widholm 1987). It is worth mentioning that citrate increased in Cu-stressed cells and remained or slightly decreased in Cu-acclimated ones. This fact could indicate that citrate synthesis is preferentially stimulated during the first time of copper exposure in these soybean cells, being one of the fastest responses to copper exposure. Two organic acids exudation responses differing in time have been observed in roots of aluminium resistant plants (for review see Mariano et al. 2005). In the former response organic acids release is rapidly activated after aluminium exposure and the rate of release remains constant with time. In this case it has been suggested that aluminium activates a constitutive mechanism of organic acids transport in the plasma membrane and the activation of genes is not necessary. Aluminium can activate anion channels, which have been proposed as the mediators of organic acids transport across the cell membranes. In the second one there is a delay in the organic acids release after the addition of aluminium and this release increases with time. In this case the activation of genes related to the metabolism and membrane transport of organic acids might be required. According to that, the rapid induction of citrate in Cu-stressed cells might correspond to a mechanism similar to that taking place in the former response. On the other hand, the slower induction of malate observed in Cu-acclimated cells might rather correspond to the second mechanism mentioned above. In this point it is clear that further experiments varying time of copper exposure are necessary to define and understand the mechanisms involved in organic acid respond to excess copper in these cells. 
Vacuole was also affected by copper treatments. Accumulation of metals in vacuoles is known as a detoxification mechanism to maintain lower metal concentrations in other subcellular compartments (chloroplast, cytoplasm, nucleus). The results showed that the cytoplasmic vacuole area increased in Cu-acclimated cells in comparison with non-treated and Cu-stressed ones. This fact can be associated with an accumulation of copper within the vacuole. Indeed, previous results showed a higher level of copper in vacuoles of $\mathrm{Cu}$ acclimated cells compared with those of non-treated ones (Bernal et al. 2006). Furthermore, the analyses did not reveal the copper accumulation in vacuoles of Cu-stressed cells (data not shown). Vacuole modifications can be associated to dynamic conversion between lytic and storage functions (Murphy et al. 2005). Our observations could indicate that in the acclimated state the detoxification relies on compartmentation through active copper pumping into the vacuole rather than on complexation by ligands, or exclusion by an active efflux or reduced uptake. The results are in agreement with a picture where the first response of soybean cells to excess copper exposure avoids its entrance to the cell by its immobilization in the cell wall, probably through citrate copper chelates among other mechanisms. Then, after an adaptive long-term exposure, the Cu-acclimation would be mainly due to vacuolar sequestration. Further research is underway to determine whether the copper tolerance developed by the soybean cell cultures is really a stable character. As preliminary result we found that the suppression of excess copper in the growth medium of Cu-acclimated cells during four subsequent transfers did not alter the copper content within the cells and their oxygen evolution-activity, which was different to that of non-treated one (data not shown). 
In summary our results indicate that the structural cell modifications, mainly affecting chloroplasts and starch, accompany a short-term Cu-induced response and they are maintained as a stable character during an adaptive period to those conditions, whereas vacuole changes rather accompany a longterm response. 


\section{ACKNOWLEDGEMENTS}

The authors thank M.V. Ramiro for her helpful technical assistance and A. Alvarez for organic acid analyses. EDX microanalyses were done at the Serveis Cientificotècnics of Barcelona University (Spain). LTSM analysis was done at the Electron Microscopy Service of the Centro de Ciencias Medioambientales of the CSIC in Madrid (Spain) with the helpful technical assistance of F. Pinto. Thanks are also due to Dr. C. Ascaso and Dr. M.A. de los Ríos for their help in the preparation and interpretation of the LTSEM analysis. M. Bernal is recipient of a predoctoral fellowship from Consejo Superior de Investigaciones Científicas (I3P Programme financed by the European Social Fund). The SB-P line was kindly provided by Prof. Jack M. Widholm (Department of Agronomy, University of Illinois at Urbana, Urbana IL). This work was supported by the Aragón Government (Grant P015/2001 and GC DGA 2004 programme) and the Ministry of Education and Culture of Spain (BFU2005-07422-C02-01; AGL200505104; BFU2005-01094). 


\section{REFERENCES}

Abadía J, Nishio JN, Monge E, Montañés L, Heras L (1985) Mineral composition of peach leaves affected by iron chlorosis. J Plant Nutr 8: 965-975

Alaoui-Sossé B, Genet P, Vinit-Dunand F, Toussaint M-L, Epron D, Badot P-M (2004) Effect of copper on growth in cucumber plants (Cucumis sativus) and its relationships with carbohydrate accumulation and changes in ion contents. Plant Sci 166: 1213-1218

Alfonso M, Pueyo JJ, Gaddour K, Etienne A-L, Kirilovsky D, Picorel R (1996) Induced new mutation of D1 Serine-268 in soybean photosynthetic cell cultures produced atrazine resistance, increased stability of $\mathrm{S}_{2} \mathrm{Q}_{\mathrm{B}}{ }^{-}$and $\mathrm{S}_{3} \mathrm{Q}_{\mathrm{B}}{ }^{-}$states, and increased sensitivity to light stress. Plant Physiol 112: 1499-1508

Ali MB, Singh N, Shohael AM, Hahn EJ, Paek K-Y (2006) Phenolics metabolism and lignin synthesis in root suspension cultures of Panax ginseng in response to copper stress. Plant Sci 171: 147-154

Allan AC, Maddumage R, Simons JL, Neill SO, Ferguson IB (2006) Heatinduced oxidative activity protects suspension-cultured plant cells from low temperature damage. Func Plant Biol 33: 67-76

Austin II J, Webber AN (2005) Photosynthesis in Arabidopsis thaliana mutants with reduced chloroplast number. Photosynth Res 85: 373-384 
Baker DE, Senef JP (1995) Copper. In: Alloway BJ (eds) Heavy metals in soils. Blackie Academic and Professional, London, s, pp 179-205

Barany I, González-Melendi P, Mityko J, Fadón B, Risueño MC, Testillano PS (2005) Microspore-derived embryogenesis in Capsicum annuum: subcellular rearrangements through development. Biol Cell 97: 709-722

Bernal M, Ramiro MV, Cases R, Picorel R, Yruela I (2006) Excess copper effect on growth, chloroplast ultrastructure, oxygen evolution activity and chlorophyll fluorescence in Glycine max (L.) Merr. cell suspensions. Physiol Plant 127: 312325

Bertrand M, Poirier I (2005) Photosynthetic organisms and excess of metals. Photosynthetica 43: 345-353

Beven AF, Simpson GG, Brown JW, Shaw PJ (1995) The organization of spliceosomal components in the nuclei of higher plants. J. Cell Sci 108: 509-518

Bidwell SD, Crawford SA, Woodrow IE, Sommer-Knudsen, Marshall AT (2004) Sub-cellular localization of $\mathrm{Ni}$ in the hyperaccumulator, Hybanthus floribundus (Lindley) F. Muell. Plant Cell Environ 27: 705-716

Ciscato M, Valcke R, van Loven K, Clijsters H, Navari-Izzo F (1997) Effects of in vivo copper treatment on the photosynthetic apparatus of two Triticum durum cultivars with different stress sensitivity. Physiol Plant 100: 901-908 
Clemens S (2001) Molecular mechanisms of plant metal tolerant and homeostasis. Planta 212, 475-486

De los Ríos A, Ascaso C, Wierzchos J, Fernández-Valiente E, Quesada A (2004). Microstructural Characterization of Cyanobacterial Mats from the McMurdo Ice Shelf, Antarctica. Appl Environ Microb 70: 569-580

De Pater S, Caspers M, Kottenhagen M, Miema H, ter Stege R, de Vetten N (2006) Manipulation of starch granule size distribution in potato tubers by modulation of plastid division. Plant Biotechnology J 4: 123-134

Ernst WHO, Verkleji JAC, Schat H (1992) Metal tolerance in plants. Acta Bot Neerl 41: 229-248

Fernandes JC, Henriques FS (1991) Biochemical, physiological and structural effects of excess copper on plants. Bot Rev 57: 246-273

Fornazier RF, Ferreira RR, Pereira GJG, Molina SMG, Smith RJ, Lea PJ, Azevedo RA (2002) Cadmium stress in sugar cane callus cultures: Effect on antioxidant enzymes 71: 125-131

Foyer C (1988) Feedback inhibition of photosynthesis through source-sink regulation in leaves. Plant Physiol Biochem 26: 483-492

Gori P, Schiff S, Santandrea G, Bennici A (1998) Response of in vitro cultures of Nicotiana tabacum L. to copper stress and selection of plants from $\mathrm{Cu}$ tolerant callus. Plant Cell Tiss Org 53: 161-169 
Gratão PL, Polle A, Lea PJ, Azevedo RA (2005) Making the life of heavy metalstressed plants a little easier. Func Plant Biol 32: 481-494

Hall JL, Williams LE (2003) Transition metal transporters in plants. J Exp Bot 393: $2601-2613$

Kabata-Pendias A, Pendias H (2001) Trace elements in soil and plants. Boca Raton, FL CRC Press

Kishinami I, Widholm JM (1986) Selection of copper and zinc resistant Nicotiana plumbaginifolia cell suspension cultures. Plant Cell Physiol 27: 12631268

Kishinami I, Widholm JM (1987) Characterization of $\mathrm{Cu}$ and $\mathrm{Zn}$ resistant Nicotiana plumbaginifolia suspension cultures. Plant Cell Physiol 28: 203-210

Kochian LV, Hoekenga OA Pineros MA (2004) How do crop plants tolerate acid soils? -Mechanisms of aluminium tolerance and phosphorous efficiency. Annu Rev Plant Biol 55: 459-493

Krämer U, Clemens S (2006). Functions and homeostasis of zinc, copper, and nickel in plants. In: Tamás MJ, Martinoia E (Eds.). Molecular Biology of Metal Homeostasis and Detoxification from Microbes to Man. Springer, pp 214-272. 
Kuo WT, Tang TK (1998) Effects of G6PDH overexpression in NIH3T3 cells treated with tert-butyl hydroperoxide of papaquat. Free Radic Biol Med 24: $1130-1138$

Küpper H, Šetlík I, Šetliková E, Ferimazova N, Spiller M, Küpper FC (2003) Copper-induced inhibition of photosynthesis: limiting steps of in vivo copper chlorophyll formation in Scenedesmus quadricauda. Func Plant Biol 30: 11871196

Lin C-C, Chen L-M, Liu Z-H (2005) Rapid effect of copper on lignin biosynthesis in soybean roots. Plant Sci 168: 855-861

Mariano ED, Jorge RA, Keltjens WG, Menossi M (2005) Metabolism and root exudation of organic acid anions under aluminium stress. Braz J Plant Physiol 17: $157-172$

Marschner H (1995) Mineral nutrition of higher plants. Academic Press, London, pp. 344-346

Moya JL, Ros R, Picazo I (1993) Influence of cadmium and nickel on growth, net photosynthesis and carbohydrate distribution in rice plants. Photosynth Res 36: $75-80$

Murphy KA, Kuhle RA, Fischer AM, Anterola AM, Grimes HD (2005) The functional status of paraveinal mesophyll vacuoles changes in response to altered metabolic conditions in soybean leaves. Func Plant Biol 32: 335-344 
O'Brien TP, McCully ME (1981) The Study of Plant Structure Principles and Selected Methods. Termarcarphi Pty. Ltd. Melbourne, Australia, pp 357

Pålsgård E, Lindh U, Roomans GM (1994) Comparative study of freezesubstitution techniques for X-ray microanalysis of biological tissue. Microsc Res Techniq 28: 254-258

Pilon M, Abdel-Ghany SE, Cohu CM, Gogolin KA, Ye H (2006) Copper cofactor delivery in plant cells. Curr Opin Plant Biol 9: 1-8

Pilon-Smits E, Pilon M (2002) Phytoremediation of metals using transgenic plants. Crit Rev Plant Sci 21: 439-456.

Quartacci MF, Pinzino C, Sgherri CLM, Dalla Vecchia F, Navari-Izzo F (2000) Growth in excess copper induces changes in the lipid composition and fluidity of PSII-enriched membranes in wheat. Physiol Plant 108: 87-93

Rai V, Khatoon S, Bisht SS, Mehrotra S (2005) Effect of cadmium on growth, ultramorphology of leaf and secondary metabolites of Physllanthus amarus Schum. and Thonn. Chemosphere 61: 1644-1650

Rauser WE (1999) Structure and function of metal chelators produced by plants. The case for organic acids, amino acids, phytin, and metallothioneins. Cell Biochem Biophys 31: 19-48 
Raven JA, Evans MCW, Korb RE (1999) The role of trace metals in photosynthetic electron transport in $\mathrm{O}_{2}$-evolving organisms. Photosynth Res 60: 111-149

Reichman SM, Menzeis NW, Asher CJ, Mulligan DR (2006) Responses of four Australian tree species to toxic concentrations of copper in solution culture. $\mathrm{J}$ Plant Nutr 29: 1127-1141

Risueño MC, Medina FJ (1986) The nucleolar structure in plant cells. Cell Biol Rev 7: 1-140

Roitsch T, Sinha AK (2002) Application of photoautotrophic suspensions cultures in plant science. Photosynthetica 40: 481-492

Rogers SMD, Ogren WL, Widholm JM (1987) Photosynthetic characteristics of a photoautotrophic cell suspension culture of soybean. Plant Physiol 84: 14511456

Satpute GK, Long H, Seguí-Simarro JM, Risueño MC, Testillano PS (2005) Cell architecture during gametophytic and embryogenic microspore development in Brassica napus L. Acta Physiol Plant 27: 523-532

Schat H, Vooijs R (1997) Multiple tolerance and co-tolerance to heavy metals in Silene vulgaris: A co-segregation analysis. New Phytol 136:489-496 
Seguí-Simarro JM, Bárány I, Suárez R, Fadón B, Testillano PS, Risueño MC (2006) Nuclear bodies domain changes with microspore reprogramming to embryogenesis. Eur J Histochem 50: 35-44

Stoyanova DP, Tchakalova FS (1997) Cadmium-induced ultrastructural changes in chloroplasts of the leaves and ítems parenchyma in Myriophyllum spicatum L. Photosynthetica 34: 241-248

Testillano PS, González Melendi P, Ahmadian P, Fadon B, Risueño MC (1995) The immunolocalization of nuclear antigens during the pollen developmental program and the induction of pollen embryogenesis. Exp Cell Res 221: 41-54

Testillano PS, González-Melendi P, Coronado MJ, Seguí JM, Moreno MA, Risueño MC (2005) Differentiating plant cells switched to proliferation remodel the functional organization of nuclear domains. Cytogenet Genome Res 109: 166-174

Van Hoof NALM, Koevoets PLM, Hakvoort HWJ, Ten Bookum WM, Schat H, Verkleij JAC, Ernst WHO (2001) Enhanced ATP-dependent copper efflux across the root cell plasma membrane in copper-tolerant Silene vulgaris. Physiol Plant 113: 225-232

Vitória AP, Rodríguez APM, Cunha M, Lea PJ, Azevedo RA (2004) Structural changes in radish seedlings (Raphanus sativus) exposed to cadmium. Biol Plant 47: 561-568 
Vitória AP, Cunha M, Azevedo RA (2006) Ultrastructural changes of radish leaf exponed to cadmium. Environ Exp Bot, in press.

Wójcik M, Tukiendorf A (2003) Response of wild type of Arabidopsis thaliana to copper stress. Biol Plant 46: 79-84

Yruela I (2005) Copper in plants. Braz J Plant Physiol 17: 145-146

Zuppini A, Bugno V, Baldan B (2006) Monitoring programmed cell death triggered by mild heat shock in soybean-cultures cells. Func Plant Biol 33: 617627 
FIGURE 1: Cu content in soybean photosynthetic cells during 21 days of

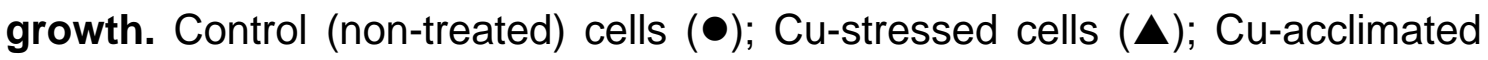
cells ( $\boldsymbol{\square})$. For details see Materials and Methods.

FIGURE 2: Structural organization of soybean photosynthetic cells of nontreated cultures. Historesin semithin sections after toluidine blue staining $(a, b$, f-h), DAPI staining for DNA (c) and $\mathrm{I}_{2} \mathrm{IK}$ staining for starch (d, e). a) Panoramic view of the cells in the culture, isolated and in two-cell groups. b) Cell structure observed at higher magnification, cells show large vacuoles (v), perypheric nucleus (N) with one nucleolus each, cytoplasm (ct) with ellipsoid chloroplasts, many of them containing clear starch deposits (arrows). c) Chromatin pattern showed by DAPI staining: nuclei exhibit an homogeneous medium-bright fluorescence and several brighter small spots aligned at the nuclear periphery, corresponding to condensed chromatin patches. The nucleoli appear as dark areas (arrows). d, e) Starch grains revealed as dark inclusions by iodide-base cytochemistry, observed under bright field (d) and phase contrast (e). f-h) Several two-cell structures showing different asymmetric position of the dividing cell wall and some details of the cell organization. In some nuclei, Cajal-like bodies (arrows) can be observed. Bars represent $10 \mu \mathrm{m}$.

FIGURE 3: Structural organization of soybean photosynthetic cells of Custressed cultures. Historesin semithin sections after toluidine blue staining (a, $b, c, f-h)$, and $I_{2} I K$ staining for starch (d, e). a) Panoramic view of the cells in the culture, isolated and in two-cell groups, showing high vacuolation. b, c) Cell 
structure observed at higher magnification: the chloroplasts (arrows) appear dense and rounded, with no clear areas inside. The nuclei exhibit small dark nucleoli each and some of them Cajal-like bodies (open arrow). Extracellular dark deposits (arrowheads) are observed in contact with the outer face of the cell walls in many cells. d, e) lodide-based cytochemistry revealed no presence of starch deposits in the chloroplasts, observed under bright field (d) and phase contrast (e). f-h) Extracellular deposits of different sizes and shapes (rounded and ellipsoid) are found on the cell walls. Bars in a, b, c, d, e represent $10 \mu \mathrm{m}$; bars in $\mathrm{f}, \mathrm{g}$, h represent $5 \mu \mathrm{m}$.

FIGURE 4: Structural organization of soybean photosynthetic cells of Cuacclimated cultures. Historesin semithin sections after toluidine blue staining $(\mathrm{a}, \mathrm{b}, \mathrm{c})$, and $\mathrm{I}_{2} \mathrm{IK}$ staining for starch $(\mathrm{d}, \mathrm{e})$. a) Panoramic view of the culture, cells appear isolated and in two-cell groups with a cell wall in asymmetric position. b, c) Higher magnification of the cell organization details: the cytoplasmic vacuole (v) appears very large in most cells, the peripheral layer of cytoplasm is thin and contains rounded and dense chloroplasts (arrows), with no clear areas inside. d, e) lodide-based cytochemistry for starch does not provide any contrast under bright field (d) revealing no presence of starch deposits in the chloroplasts which are observed under phase contrast (e). Bars represent $10 \mu \mathrm{m}$.

FIGURE 5: Low Temperature Scanning Electron micrographs of soybean photosynthetic cells of non-treated (a), Cu-stressed (b) and Cu-acclimated (c) cultures. Etching of frozen native samples. The aqueous content of the vacuole (v) appears forming a reticulum due to the freezing. In the peripheral 
layer of cytoplasm (ct) the chloroplasts are observed as spherical structures, in non-treated cultures, most of them contain inner large structures, starch grains (arrows in a). Bars represent $5 \mu \mathrm{m}$.

FIGURE 6.- Energy dispersive X-ray spectra of extracellular dark deposits attached at the cell wall in Cu-stressed soybean photosynthetic cells. a) cell wall of non-treated cells; b) extracellular dark deposits. Typically, 6 cells of each type were analysed. Y-axis scale for b) was 4-fold. 
TABLE 1. Morphometric analysis of cell, chloroplast and vacuole size from soybean cell cultures grown in control media (Non-treated), media supplemented with $10 \mu \mathrm{M} \mathrm{CuSO}{ }_{4}$ during 21 days of growth (Cu-stressed) and after 22 transfers (Cu-acclimated).

\begin{tabular}{|c|ccc|}
\hline Cell cultures & Cell $^{1}$ & Chloroplast $^{1}$ & Vacuole $^{1}$ \\
\hline Non-treated & $209.6^{\mathrm{a}} \pm 34.8$ & $7.5^{\mathrm{a}} \pm 1.2$ & $103.8^{\mathrm{a}} \pm 22.2$ \\
Cu-stressed & $185.4^{\mathrm{a}} \pm 26.2$ & $3.7^{\mathrm{b}} \pm 0.7$ & $111.4^{\mathrm{a}} \pm 17.4$ \\
Cu-acclimated & $220.6^{\mathrm{a}} \pm 38.0$ & $2.3^{\mathrm{c}} \pm 0.5$ & $138.0^{\mathrm{b}} \pm 25.4$ \\
\hline
\end{tabular}

${ }^{1}$ area in $\mu \mathrm{m}^{2}$

${ }^{a, b, c}$ For the same column, different letters indicate significant differences at $p \leq$ 0.05. Data were obtained on average from 15 images for each condition. 
TABLE 2. Organic acid content of cells from soybean cell cultures grown in control media (Non-treated), media supplemented with $10 \mu \mathrm{M}$ $\mathrm{CuSO}_{4}$ during 21 days of growth (Cu-stressed) and after 22 transfers (Cu-acclimated).

\begin{tabular}{|c|cc|}
\hline Cell cultures & Citrate $^{1}$ & Malate $^{1}$ \\
\hline Non-treated & $2.4^{\mathrm{a}} \pm 0.2$ & $0.3^{\mathrm{a}} \pm 0.1$ \\
Cu-stressed & $7.6^{\mathrm{b}} \pm 0.3$ & n.d. \\
Cu-acclimated & $5.9^{\mathrm{c}} \pm 0.2$ & $1.1^{\mathrm{b}} \pm 0.3$ \\
\hline
\end{tabular}

${ }^{1} \mu$ moles $g^{-1}$ fresh weight

${ }^{a, b, c}$ For the same column, different letters indicate significant differences at $p \leq 0.05$. Data were obtained on average from 15 images for each condition. 


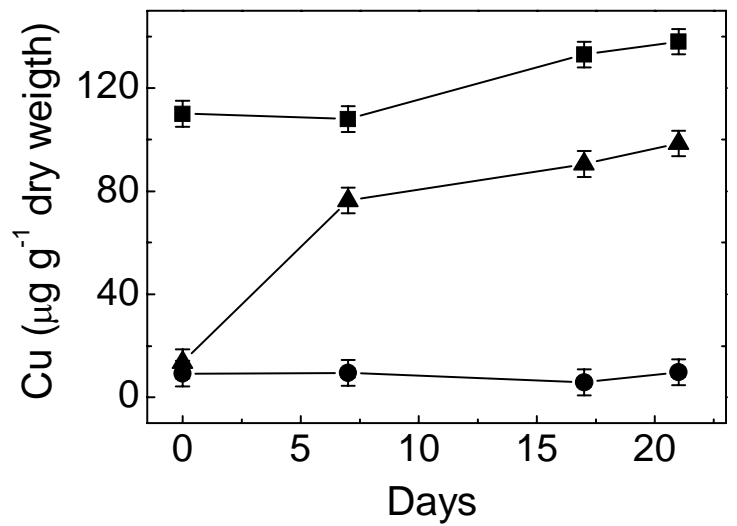

Fig. 1 


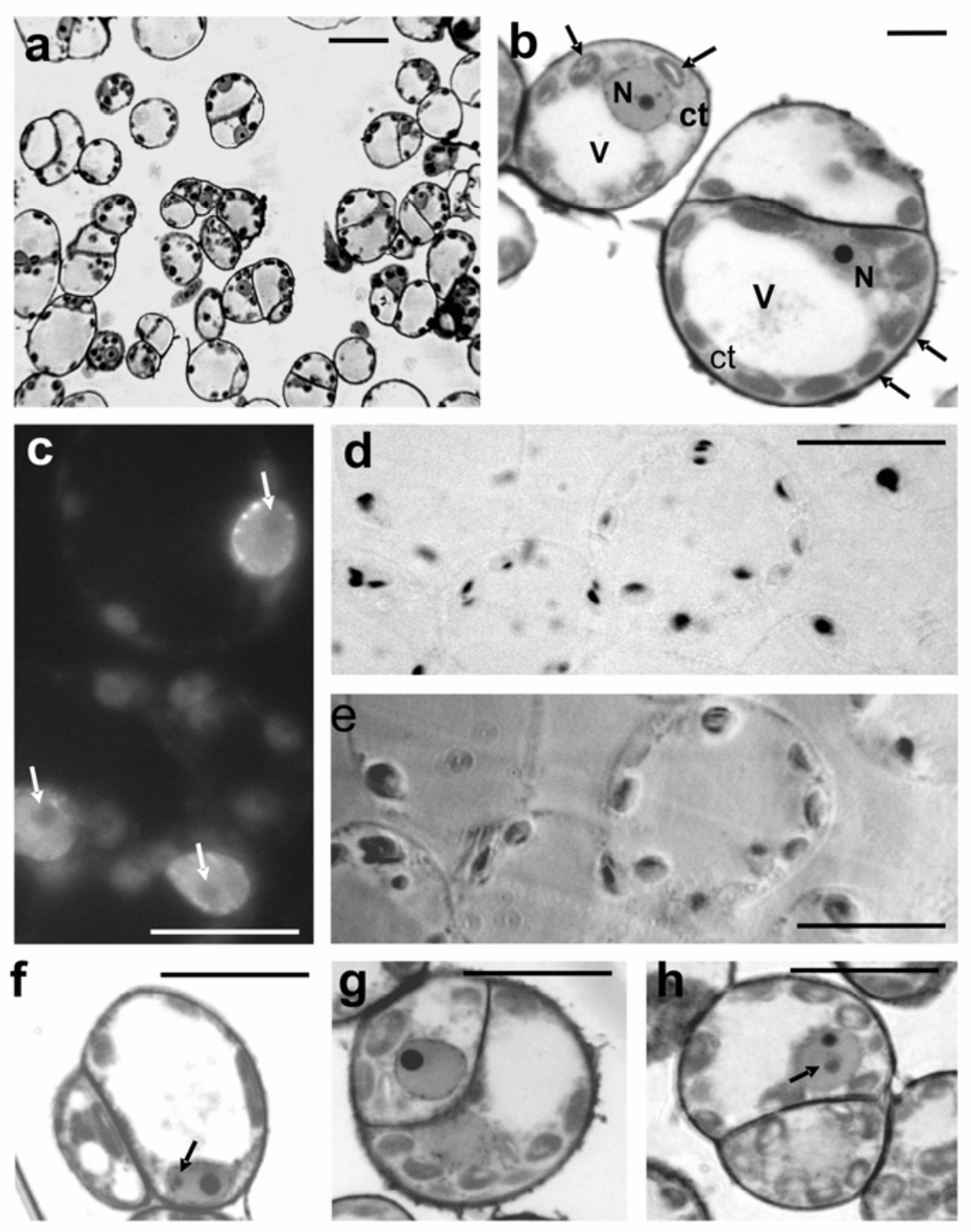

Fig. 2 


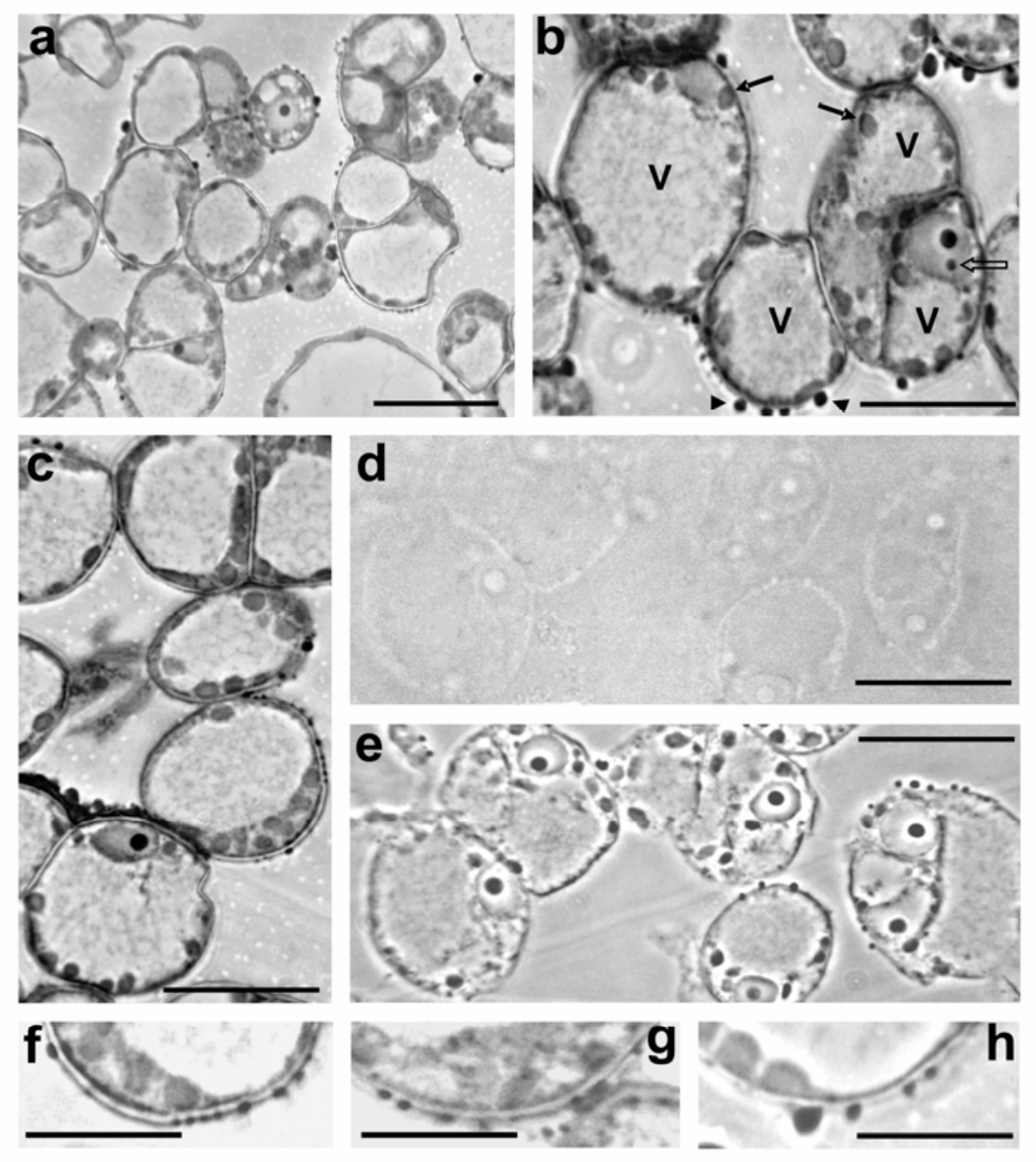

Fig. 3 

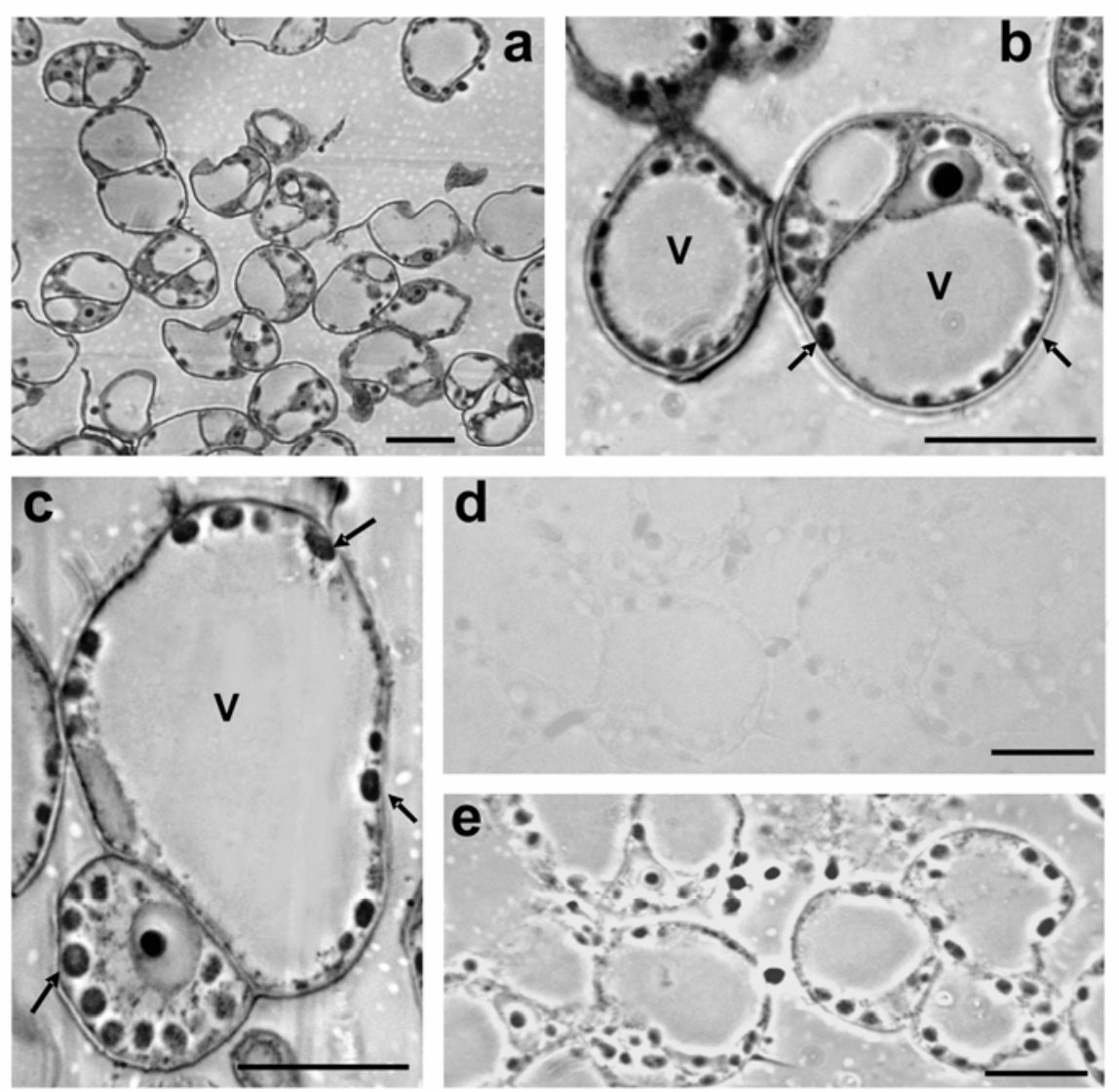

Fig. 4 


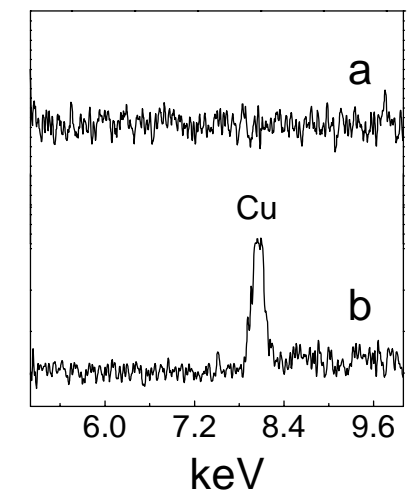

Fig. 6 

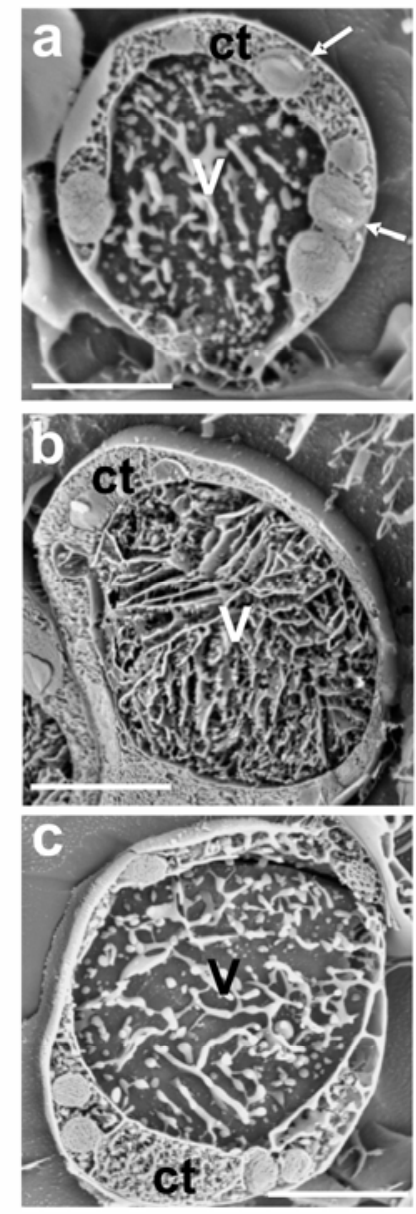

Fig. 5 